\title{
CHINESE INVESTORS INVESTMENT STRATEGIES \\ IN THE AUSTRALIAN RESIDENTIAL PROPERTY MARKET
}

PENG YEW WONG', DAVID M. HIGGINS ${ }^{2}$, RON WAKEFIELD ${ }^{3}$

\begin{abstract}
Active participation by foreign investors in Australian residential property market is a common sight subsequent to the Global Financial Crisis 2008 (GFC 2008) and many of them purchased residential properties in the Australian capital cities. House prices rose by $6.0 \%$ in 2014 and $5.0 \%$ in 2015 in the Australian capital cities (NAB, 2014) and an estimated 18\% of new dwellings in Sydney and 14\% in Melbourne were purchased by foreigners in 2014 (Allen, 2015).

This research focuses on the emerging determinants for the Australian residential property market. This research was the first to conduct cross border semi-structured interviews in Shanghai, China to uncover historical evidence and emerging supporting the existence of a significant relationship between overseas investors and residential housing markets performance in Melbourne. Some unique investment strategies of the private investors from China which emphasised on noncapitalist factors such as early education and residential tourism were identified, alongside with some insights on the significant China government policies that have incentivised the cross border investments from China. It is believed that this understanding will assist the policy makers to effectively manage the overheated Australian residential property market without compromising the steady flow of Foreign Real Estate Investment (FREI).
\end{abstract}

Keywords: Residential Property, Foreign Real Estate Investment (FREI), Cross Border Investment, Private Investment, China Government Policies, Residential Tourism.

\section{INTRODUCTION}

\subsection{The Australian Residential Property Market}

Foreign investors in Australian residential property market have been active subsequent to the GFC 2008 and their participations represented $16 \%$ of the Australian new housing markets sales in 2014 (NAB, 2015). A NAB (2014) survey shows that in the first half of 2014, house prices in both Sydney and Melbourne were at record high level. Some media claimed that house prices had moved beyond the reach of the majority local buyers especially in the desirable locations (AFR, 2014, Birrell, 2013, Economics, 2014). Chinese investors and newly arrived migrants were singled out as the major FREI buyers in Australia and they are expected to invest approximately AUD44 billion into Australia residential real estate market by 2021 (Janda, 2014). Figure 1 shows the Australian Bureau of Statistics (ABS) Australian housing index for the period 2007 to 2015: 
Figure 1: $\quad$ Australia Housing Price Index 2007 to 2015

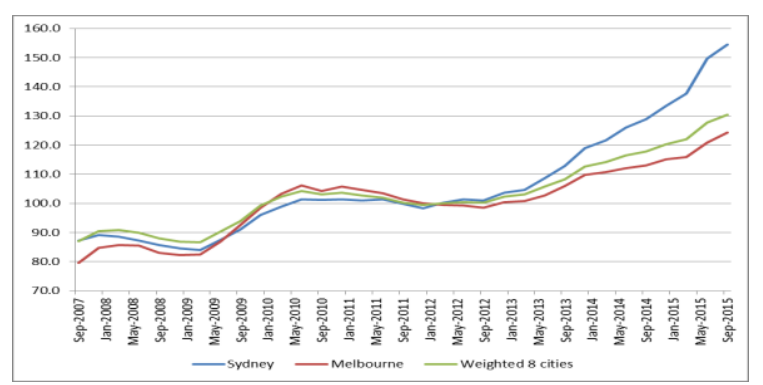

Source: ABS 2015

Figure 1 shows that from 2007 to 2015, residential property price grew 50\%, 56\% and $77 \%$ respectively for the weighted average of eight Australian capital cities, Melbourne and Sydney. Figure 2 shows the trend of number of residential real estate approvals for foreign investors in Australia from 2006 to 2012.

Figure 2: $\quad$ Residential Real Estate Approvals for Foreign Investors

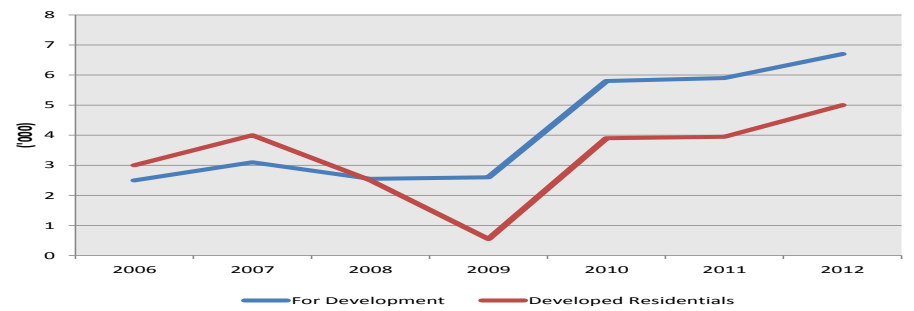

Source: FIRB 2014

Figure 1 and 2 show the significant lift in both the Australian house prices and the foreign interest in the Australian residential property market. In 2014 the Australian Treasurer lodged a formal inquest to the Australian Foreign Investment Review Board (FIRB) to investigate into the Australia's foreign investment policy related to Australian residential real estate. It was believed that the government's attention of foreign buying came as a result of numerous news articles and publications on the surge in house prices in Australian major cities such as Sydney and Melbourne (Economics, 2014). The inquiry was a clear indication for a need to research for drivers that caused the foreign investments in the Australian residential property market.

The focus of this study is to determine whether there are historical evidences of a relationship between overseas investments and the residential housing markets performance in Melbourne with aims to explore the emerging determinants that attracted offshore purchases in Melbourne residential properties. This study is expected to yield empirical evidence that will assist policies makers in making informed decisions to promote foreign investments yet maintaining the affordability of housing market in Australia. The result of this study is believed to yield findings that can assist the researcher, property market operators and investors in the evaluation of foreign investments in the Australia residential housing market.

\section{LITERATURE REVIEW}

\subsection{The Growth of Asia Pacific Private Wealth and The Global Cross Border Investment}

Foreign Direct Investment (FDI) in real estate markets had experienced significant growth in many countries (UNCTAD, 2011). The increasing cross border activities in real estate market was particularly noticeable from China which observed FDI in real estate market went up to almost 50\% of the total FDI in China In 2012. In India, real estate ranked second only to India's computer 
software industry in 2007 FDI (Economist, 2008). Evidently, cross border foreign real estate investments is on a rise in this global liberalization era (D'Arcy, 2009, Topintzi et al., 2008, UNCTAD, 2009, UNCTAD, 2013).

A recent trend emerged after the GFC 2008 with the Sovereign Wealth Funds (SWF), wealth management companies, private bankers and wealthy families stepping into the cross border property market activities that corporate bankers deserted. The rising private wealth in Asia Pacific was believed to be the driver that increased the cross border investment activities seeking higher return and diversification (KPMG, 2014, Savills, 2014). The growth of High Net Worth Individuals (HNWI) in Asia and their investments in cross-border real estate transactions had impacted the world real estate investment landscape (KPMG, 2014).

In a similar manner and perhaps on a different magnitude, the growth of the global emerging middle class (Expanding Middle) is set to shift the world economy dynamic and consumption pattern. Goldman Sachs (2008) projected that:

i. The rise of Expanding Middle (EM) will shift the global consumption pattern moving away from the rich or developed countries to the middle-income economies.

ii. By 2050, the middle-income economies will be responsible for close to $60 \%$ of the world's GDP.

iii. A massive global middle-class growth is anticipated to shape new patterns in spending, resource use, environmental and political pressures.

Source: Goldman Sachs 2008

China and India are at the centre of this significant event. The rise of the EM can drive a broad range of economic, social and political revolutions to a scale not seen since the formation of the developed countries' middle classes in the second half of the $19^{\text {th }}$ century. Numerous empirical studies had made similar predictions on the growth of middle class, see Kharas (2010), Wilson (2008) and Ernst\&Young (2013). In 2000, Asia (excluding Japan) only accounted for 10 per cent of the global middle class spending. By 2040, this could reach $40 \%$ and may continue to rise to $60 \%$ in the long-term (Kharas, 2008). The observation from OECD appears consistent with these findings as illustrated in figure 3 below:

Figure 3: $\quad$ The Emerging Global Middle Class

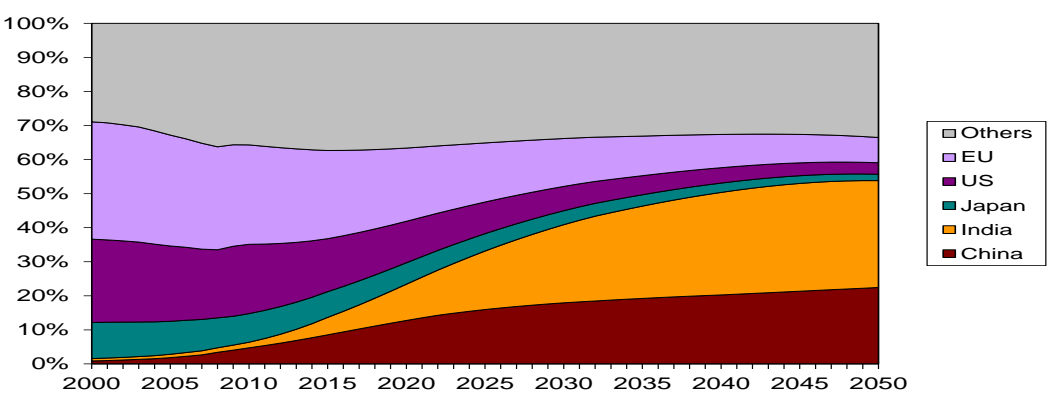

Source: OECD 2010

A significant proportion of the new Asian middle class is also expected to be at the upper end of the income bracket and boast impressive spending power. The steep increase in Asian demand and the replacement of US demand is clearly seen as a trend that accelerates in the coming decade (Kharas, 2010).

\subsection{Chinese Investment in Australian Residential Property Market}

Choices of overseas investments from China Outward FDI are not limited to Australia. According to Ernst\&YoungChina (2015), Chinese investors invested in 6,128 overseas companies across 156 countries and regions for the year 2014. Out of the total USD116 billion outward FDI from China in 
2014 (excluding Hong Kong, Virgin Island and Cayman Island), approximately USD 33.9 billion (or 29.2\%) went to the rest of the world. Figure 4 shows China Outward FDI top destinations from 2009 to:

Figure 4: $\quad$ China Outward FDI Top Destinations (USD million)

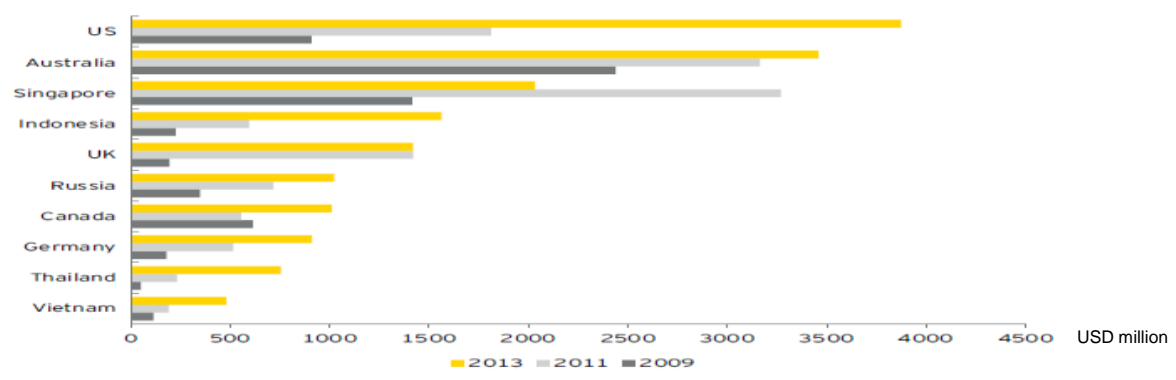

Source: Ministry of Commerce China; adapted by Ernst \& Young

Australia ranked the second highest beneficiary of China outward FDI after United States to receive more than USD3.5 billion in 2013. China's investments in Australian fixed assets and real estate contributed to more than 10\% of the total China Outward FDI in 2013 with Australia being the favourite destination for Chinese money. In reality, the total China Outward FDI to Australia could have been larger if not for exploitation by some investors on various loopholes to move money offshore from China (Ernst\&YoungChina, 2015). Based on these official statistics and projections, strong basis was established that the Chinese were expected to invest approximately AUD 44billion into Australian residential property market over the next seven years (Janda, 2014) and exceeding AUD5billion a year (Economist, 2014).

\section{Foreign Investment Traditional Determinants}

The main attractions cited for the top foreign investment destinations include stable political and social environments, sound legal and regulatory systems, successful market system, and leading competence in science and technology and education. The drivers cited by Schiesinger (2015) on Chinese investors buying into Australian residential property market were better investment fundamentals, the opportunity to acquire freehold property, higher yields, more stable economic environment and the ability to borrow up to $80 \%$ in Australia. The other two main reasons were availability of education for children to study in Australia and this in turn forms part of a future plan to migrate to Australia due to better living conditions (KPMG, 2014). Other major factors that drove the housing market demand in Australia include:

i. The population growth attributable by an increased level of skilled migrant intake. The recent migrants were equity strong and they purchased residential properties sooner than many unskilled migrants.

ii. Competition with mining and infrastructure for skilled labour and materials had limited the supply of residential properties.

iii. Higher number of granted education visas.

iv. Real estate has a proven track record for self-managed super funds.

Source: CommonwealthBank 2014

In the midst of FREI activities in the Australian residential property market, Commonwealth Bank (2014) highlighted that the normal investment theory and law of demand and supply was perceived inadequate to explain the reasons of offshore investors' preference in Australia residential properties over other parts of the world. There is an apparent lacking of studies assessing the recent real estate investment decision models from a different perspective based on the emergence of new 
economic fundamentals subsequent to GFC 2008. A more extensive research into factors causing the surge of housing demand in Australia cities has become desirable.

\subsection{Residential Tourism (RT) - Non-traditional Determinant}

In an effort to fill the gap of these evolving factors contributed to the latest surge in housing demands in Australian cities, this study explored an existing European tourism migration trend that closely resembled a new social development in Australia. RT is a term commonly used by estate agents, newspaper, academics and officials in Spain referring to the coexistence between property ownerships and the short to medium term residencies of the North-Europeans in Spain tourist areas. Residential Tourist (RTs) definitions distinguish them as an affluent group that treats tourism as a way of life and they construct fluid, leisure lifestyles between places. They are also being characterized as tourists who have ostensibly try to settle, although they still remain in some ways outside or above the community they have moved to (O'Reilly, 2007, Rodríguez and Bustillo, 2010). According to O'Reilly (2007), it had been difficult to disentangle migration and tourism activities in Europe.

Subsequent to GFC 2008, a similar social development was observed in Asia Pacific region. Wealthy private individuals from Asia are playing a major role in cross border residential properties transactions which observe Chinese buyers purchased properties for their offspring and to secure lifestyle improvement in world major cities (Savills, 2014). This unique interaction between tourism and migration in Europe possesses direct resemblance to the Australian tourism-migration trend in recent time. Changes to living standards among all upper middle class and HNWIs may influence immigration and tourism in both the source country and the destination. The rising living standards and the emergence of an affluent middle class in the newly industrialising countries of North East Asia have led to an increased number of those who are able to afford to visit Australia as tourists or take advantage of the skilled migration category for the purpose of emigration. (Dwyer et al., 1993, Dwyer, 2010, King, 1994, Williams and Hall, 2002). A model proposed by Williams and Hall (2002) depicted tourism activities as stimulus for migration and migration as an inducement to tourism flows. Such relationships were explored in the context of geographical extension of friendship, ethnic and kinship networks. Dwyer et al. (1993) suggested that permanent migration and tourism were linked and the link operated in both directions. Visiting Friends and Relative (VFR) tourism is an important element of what they termed "chain migration". These links were analysed in the Australian context in a study commissioned by the Bureau of Immigration and Population Research, which used immigration and tourism data as its key information source (Dwyer et al., 1993). Boyne et al. (2002) argued that migration was a prerequisite for VFR tourism.

Towards the middle of year 2015, Melbourne was again named the most liveable city for the fifth consecutive year by The Economist's (Lucas, 2015). Lord Mayor Robert Doyle proclaimed that the latest ranking provided a very important sale point for Melbourne in a very competitive tourism and education market. Australia is set to issue more than five million visas in year 2015, something not seen since World War II with a significant jump in the visas issuance to international students, tourists and workers on short-term visas (Garnaut (2015).

\subsection{Education}

A review of empirical studies uncovered many studies had established that education or more specifically, tertiary education as one of the main drivers for the success of immigration program in Australia. A significant proportion of these students contemplating migration at the conclusion of their studies and purchasing residential properties was a natural path for these migrants. (Dwyer et al., 2010, Hawthorne, 2010, Pascoe, 2015, Verbik and Lasanowski, 2007).

As immigration activities increased in scale, migration to and from Australia had become increasingly complex. There were evidences that migration had geared towards greater diversity with improved flows of skilled migrants as well as refugees, students and even short term 
employment seekers or the transilient migrants (Coles and Timothy, 2002). The new emerging trend of private wealth from Asia Pacific has further introduced a new dimension to this complexity. These diversity of migrant movements, specific reference is made to the increased tendency of graduates in Australia taking up permanent residency status in Australia, had added to the complexity in the studies of various attributes contributing towards the inward migration to Australia. The unique characteristics of private wealth playing great emphasis on lifestyle, preservation of wealth and education for their next generations had introduced a new relationship between education and their investment activities. Along with their intension of wealth preservations, many HNWIs and/or the global middle class had sent their children overseas for further education with the ultimate intension of migrating. It is believed that this distinct requirement had resulted in many HNWIs and/or global middle class investing in the residential property markets either for owner occupying or wealth preservation purposes. Although much was deliberated on the relationship between education and migration activities, there was no specific study conducted on how education in Australia is influencing the residential properties performance in the context of private wealth investment activities in Australia.

\section{Methodology}

This study intends to focus on investigating factors that drive Asia Pacific's private wealth into Melbourne residential property market, specifically the private wealth from China. This study is therefore an extension of the prior literatures and makes allowance for emerging factors and determinants of FDI in the Australian real estate market. When combined with the existing set of variables, these emerging determinants subsequent to GFC 2008 provide potentially a better explanation on the recent phenomena of foreign investments in Melbourne residential market.

\subsection{The Model}

While research is able to determine the relationship of individual economic variables to the house prices, it tends to neglect the fact that most factors interact simultaneously with varying intensity and at different time periods to house prices (Higgins, 2010). This research intends to rely extensively on a research model providing the much needed systematic platform for emerging determinants investigation. The three-market model illustrated by Higgins (2010) which emphasised on the critical relationship between property, space and capital markets constitutes the research platform for this study. Offshore elements and influences will be systematically built into the research modelling to facilitate organised analysis on capitalist factors (for example: real estate transparency, financing cost, per capital income, rent growth) and non-capitalist factors (for example: education and tourism).

Following the review of various studies conducted specifically on FDI investments abroad, it is conclusive that of equal importance, if not more, should be placed on the investigation on the source of FDI in determining the factors affecting FDI in the host country. Moshirian and Pham (2000) explored determinants of US investments in real estate abroad based on FDI model, by comparing FDI in real estate as a subset of FDI in general. Exchange rates, size of the share market, balance of payments, trade flows, cost of capital, economic growth were identified as major "push factors" for investment in real estate abroad (Culem, 1988, Cushman ,1987, Frey et al., 1985, Froot et al., 1991, Goldberg and Johnson, 1990, Nigh, 1986). Based on the essential fundamentals of Higgins (2010) model, Figure 5 illustrates the proposed "Push \& Pull" model accomodating an additional assessment platform accomodating the impacts on Space and Financial markets from the overseas country's drivers: 


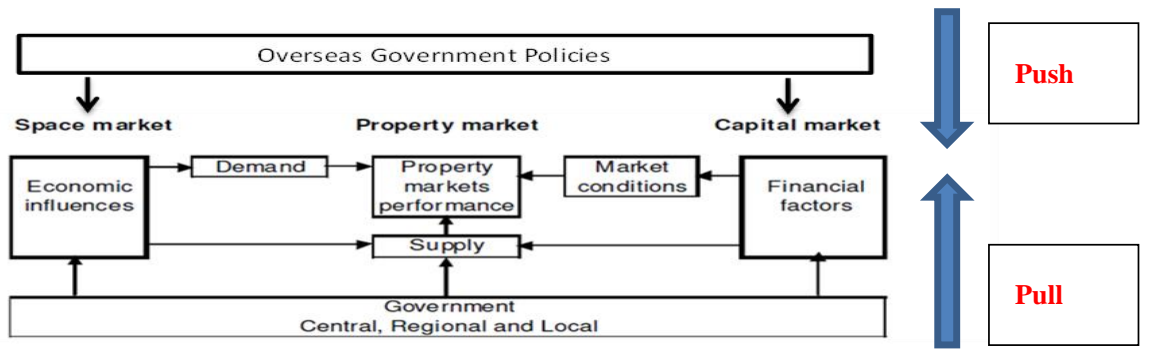

Figure 5 illustrates an added component of 'Overseas Government Policies' (from which the offshore investors originated) that impacts and influences the space and capital markets of the host country has been incorporated in the "Push \& Pull" model. It is believed that the resultant economy conditions of the offshore government policies have meaningful influences over the foreign investment outflow from the source country and emerges as impactful effects over the Space and Capital market in the host country. Importantly property market supply conditions are very much associated with the policy implementation of local government agencies or in other words, not related to offshore government policies. The "Push \& Pull" model provides the fundalmental platform of assessment for various determinants of foreign investments into the Melbourne residential properrty market for this study.

\subsection{Qualitative Research - Semi-structured Interview}

This research technique uses a qualitative assessment approach with a semi-structured interviews selected for the study. It is the aim of any qualitative research interview to incorporate a range of approaches into the interviewing process and to see the research topic from the perspective of the interviewee, specifically to understand how and why he or she arrives at a particular perspective (King, 1994, Teddlie and Yu, 2007). The evaluation of new determinants in Melbourne residential property market can be construed through feedbacks and discussions with the relevant stakeholders. King (1994) and Teddlie (2009) affirmed that a questionnaire can be qualitative (openended/unstructured), quantitative (closed-ended/structured) or mixed methods (semi-structured). This method allows for a focus on a particular unit of analysis rather than a collection of analysis of data (Willig, 2013, Yin, 2013).

The qualitative semi-structured interview in this study has the following aims:

i. To identify factors, referring to the Space and Capital markets, influencing the overseas investors' decision on Australian residential property market

ii. To identify government policies and to understand the rationales and extend of such government policies causing offshore investments in Australian residential property market

iii. To evaluate the impact of non-traditional factors had on overseas investors decision making

Chinese property professionals will be targeted as interviewees for the study and the participants comprise of a wide range crossed sectional experts from China property market. The selection of interviewees shall be based upon their involvement in the residential property industry and seniority in their respective organisations decision making process. Figure 6 illustrates the interview approaches adopted in this study to ensure adequate and strategic coverage of key players in the Chinese property industry: 


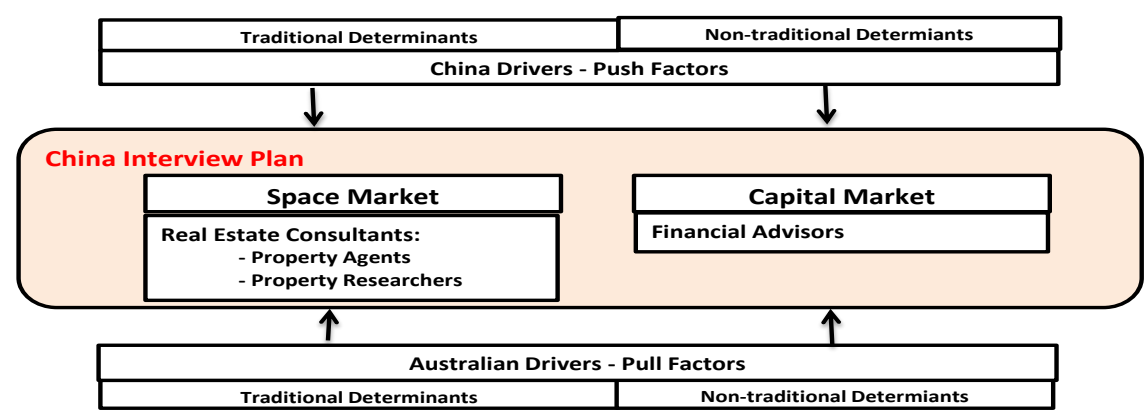

Figure 6 demonstrates the interview plan for key stakeholders in China. Three key professional were identified as key stakeholders comprise of financial professionals, property agents and property reserchers. A minimum of one participant from each category was interviewed to ensure a wide range of opinions and experiences were included as part of the data sources. Questionnaries were formulated specifically for China (Appendix I) involving a total of 8 interview questions. Codes have been assigned to each interviewee (Appendix II) to ensure the responses were deidentified, providing anonymity for the participants. These codes are used to report interview responses. Ethics approval was duly obtained from RMIT University Design and Social Context College Human Ethics Advisory Network (CHEAN) on the $14^{\text {th }}$ October 2014.

The interviews were undertaken in June 2015 at the interviewee's place of work, lasting between 30 and 60 minutes covering among others, government policies, information on foreign investors, property market conditions, tourist arrival and international student enrolments information. Interview participants were identified through the authors' and RMIT University's networks. In this research data collected from semi-structured interviews will be used to both discover the emerging trends in Australian residential property market. The qualitative data collected (descriptive and narrative) were audio recorded and transcribed. The transcripts were thematically coded using the qualitative analysis software, NVivo.

\section{Outcome}

\subsection{Emerging Local Determinants - Pull Factors}

\subsubsection{Residential Tourism}

All interview participants agreed that Australian cities carry strong brand name internationally in terms of being a tourist destination and their liveability. This brand message and presence contributed favourably to the tourism industry in Australia. Liveability was the major aspect that caught the attention of the world community and Australian cities enjoyed high ratings in the five categories stipulated by The Economist's i.e. stability; healthcare; culture and environment; education; and infrastructure. Foreigners who visited Australia were impressed by its world class education, healthcare, social security and admirable living standards, compared to other world major gateway cities such as Singapore and London. This very much sought after liveability status had not only positioned Australia as the world tourist destination in the short term basis, it had undoubtedly placed Australia as a strong contender for the world community's choice of a place to live and retire in the long run.

\section{Quotes from Participants:}

"(Australia) is it hot for Chinese tourism, is it hot for Chinese immigration, is it hot for Chinese education immigration..."(China-Global-Property-Researcher1) 
"for Australia...It's about the society, it's about the weather, it's about access to different sports and the seaside, and that type of stuff... when you talk about Australia, it's about the Australian lifestyle, it's about the great outback..." (China-Global-Real-Estate-Agent).

"Good lifestyle...Australia...most of the Chinese people they prefer Sydney, Melbourne city... people seeing clean and good education, good health, government social benefit and safe." (China-Local-Real-Estate-Agent)

".....and another of the key reasons for going overseas, obviously lifestyle, food quality, air quality, education, health care, all these other things. "(China-Global-Real-Estate-Agent)

"if you want to purchase property, you will consider living environments, climate, you know, something like that for Australia."(China-Local-Property-Consultant)

Residential Tourism (RT) is not a mainstream subject for property market research effort compared to other determinants such as Education and Migration. According to O'Reilly (2007), it had always been difficult to have separate discussions distinctly between migration and tourism. Similar challenge was observed in this research. An added element of "open-ended" approach was incorporated in the second part of the interview process to solicit "not so obvious" information surrounding the subject matter. Most of the time, it was only after a series of discussions would the participants came to realize that "residential tourism is existed in this part of the world". Figure 7 shows the Nvivo coverage analysis on the significance of RT as a key driver for offshore investment in Australian housing market:

\section{Figure 7: $\quad$ Residential Tourism - Nvivo Coverage Analysis}

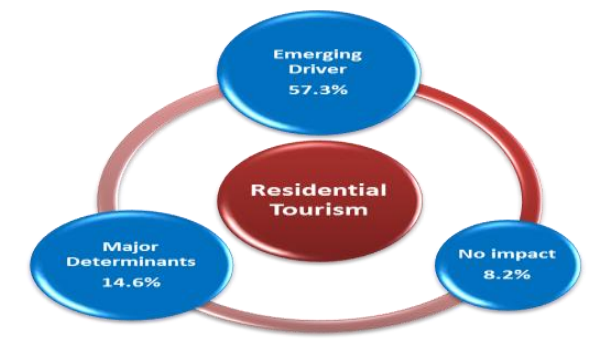

Figure 7 shows that $57.3 \%$ of the participants agreed that RT is an emerging driver of Australian residential property market. $14.6 \%$ opined RT as the major determinant and $8.2 \%$ perceived RT has no impact on Australian residential property market. The balance of the coverage (19.9\%) did not mention or not aware of RT as a potential driver.

\section{Residential Tourism - Insights}

The interviews highlighted the RTs in Australia demonstrate two distinct characteristics as below:

i. High Net Worth Individuals (HNWIs) - this group of foreign investors do not position permanent residency as their top priority. They are the affluent foreign investors who treat tourism as a way of life and conduct fluid, leisure lifestyle between major gateway cities in the world. They purchase residential properties in Australia with the primary objective of enjoying Australia's favourable living conditions as tourists and along the way, impute business strategies into the assets they purchase, reaping both rental yield and capital returns.

ii. Middle class - contrary to the HNWIs, enjoying the benefit of a good education, securing favourable living conditions for their children and eventually obtaining the permanent residency status are the top priorities of this group of investors. There exists a special emotional value underlying their investment in the Australian residential property. They intend to secure their kids in a better environment to grow and be educated. With the ultimate intention of attaining permanent residency in Australia, this group of investors often 
travel to Australia as tourists in the beginning and soon after, their visitations become a repetitive affair as their children attending Australia colleges. The different approaches to the RT by Chinese investors is shown in figure 8:

Figure 8: Residential Tourist Characteristics and Decision Making Process
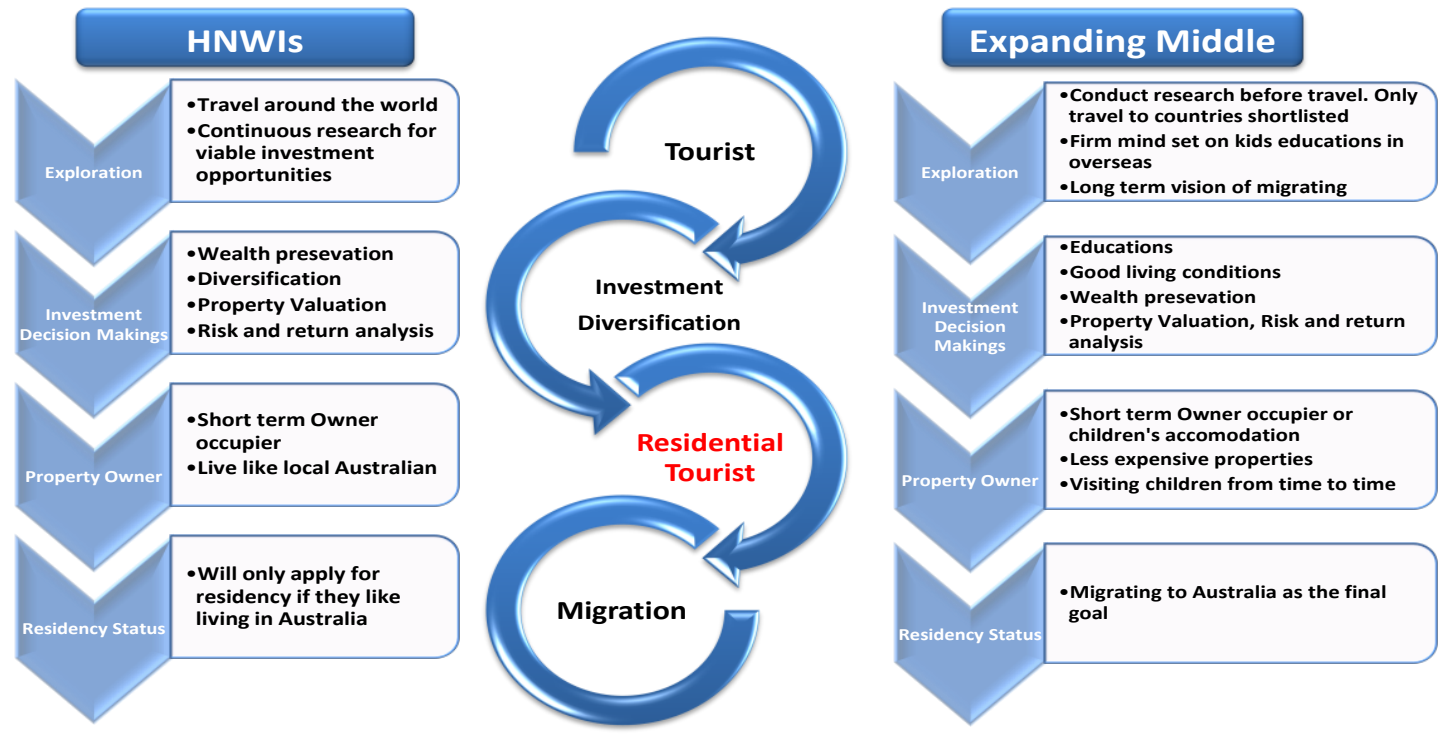

Figure 8 demonstrates the different characteristics and decision making process of HNWIs and Expanding Middle class. HNWIs emphasize on investment diversification and wealth preservation for their investment in overseas market. More likely than not, the middle class would have already made up their mind to eventually migrate to Australia at the point of them purchasing an overseas property for their children's education.

\section{Quotes from Participants:}

"As society gets richer...in the States they call it snow geese... where you've got the rich Jews from New York buying up property in Florida...maybe Chinese New Year period or sort of November December time, if they decide it's a bit too cold in China, why not take a sort of two week break down to Australia it being obviously summer time down there? That could be an increasing phenomenon going forward I think."(China-Global-PropertyResearcher1)

“...maybe stay there once or twice a year or be a holiday home, then of course you'll have a familiarity with that location, you may go visit it prior to actually purchasing...I think it's not just Chinese Nationals, but I'm sure a lot of high net worth individuals..."(ChinaGlobal-Real-Estate-Agent)

"Over the last 10 years or so we've seen more Chinese people travel abroad, so they've been exposed to the life overseas, and they've got a better impression of the quality of life that they can have in certain markets and certain regions. So that's also stimulated investment abroad"(China-Global-Property-Researcher2)

"there's also some people that perhaps are from middle income or upper middle income, they don't have to necessarily be high net worth individuals.... Some of them can be looking at migration, in which case...they could just be scraping in to get enough money to be able to buy a property in the overseas market."(China-Global-Real-Estate-Agent) 


\subsubsection{Education}

All participants in the semi-structure interview highlighted that Education in Australia played a vital role in feeding the source of foreign money purchasing Australian residential properties. Hawthorne (2010) termed this a "two-step migration" reflecting the situation that all international graduates utilised the temporary graduate visa as a transition to be eventually qualified for a permanent residency. The pathway of enrolling as a student in Australia to eventually being granted the temporary graduate visa had allowed an international student remain in Australia for an extended period of time after their graduation. Purchasing a residential property was a natural path during this period for the original international students with the long term perspective of becoming a permanent resident in Australia.

\section{Quotes from Participants:}

".. from my experience with my friends, most of them chose to migrate because they want their kids to have a different type of education.."(China-Global-Financial-Consultant)

"I think because... China is more and more open and they realise that they can learn a lot of things from the world...If they have enough financial support they want their kids go abroad for study"(China-Local-Property-Consultant)

"They (Education) are big attractions to Chinese students and parents would like to buy one or two (residential properties), one for stay one for rent.... when they have kids, they focus on the education."(China-Local-Property-Consultant).

\section{Education - Insights}

High awareness among all the participants on Education as a determinant in Australian residential property market was consistent with the empirical evidences. Whilst the empirical reviews had centred on studies in migration trend in relation to the higher educations, this study discovered that higher risk appetite from overseas investors had resulted in an emerging trend of many overseas parents sending their children to Australia in their early years for Education. The research revealed that residential properties surrounding university, higher ranked secondary and primary school zones in Melbourne were experiencing significant international student enrolments. This emerging trend of Chinese parents sending children to Australia in their earlier years were validated in the semi-structured interviews. Figure 9 demonstrate the Nvivo coverage analysis on interviewees' responses:

\section{Figure 9: $\quad$ Education - Nvivo Coverage Analysis}

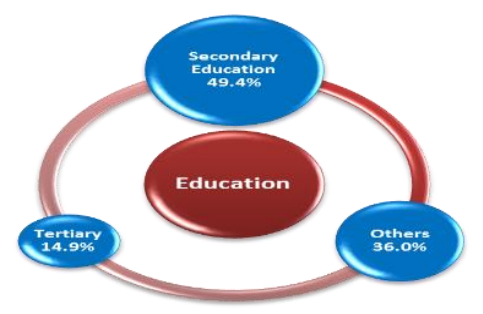

Based on Nvivo coverage analysis on the subject matter of "Education" category, there were approximately $49.4 \%$ of the interview discussion centred on education as a driver from the perspective of Secondary Education in Australia, 36.0\% coverage talked about other education formant (for example primary education and short term courses) and $14.9 \%$ of the interview coverage talked about tertiary education as the main driver. This study revealed the insights that instead of the normal duration of tertiary courses enrolment historically, international students were residing in Australia for a much longer period and this trend had further incentivised overseas parents to purchase residential properties in Australia. The main attributes resulting in Chinese parents are becoming more inclined to send their children to Australia in their earlier years are: 
i. China education system was perceived to be rigid and lacking on innovations.

ii. Students' results were based heavily on their capability to memorise and answer standardised examination questions.

iii. Chinese parents were more inclined to provide a more conducive learning environment for their children with one that is not purely based on examinations results

iv. Education institutions in China were highly competitive and the reputation of the education institutions precedes the students' academic performance.

v. Chinese parents were increasingly reluctant to subject their children to the highly pressurised competitive environment and perceived western education as providing better learning environment.

vi. Decades of "single-child" policies in China had created a high degree of protectionism among the parents to shelter their children against extreme competitive study environment.

\section{Quotes from Participants:}

"Most of them chose to migrate because they want their kids to have a different type of education..... believe the Chinese education is more like - more on examination practice focus .....they perceived the education style in maybe US or in Australia or Canada or Europe are geared to encourage kids to learn and to develop their own way of thinking..." (China-GlobalFinancial-Consultant).

“... it's(China Education) not good for the children in terms of independent thinking. They are trying to get passed the test. So the parents are quite worried about that."(China-LocalProperty-Researcher).

"And you also have to understand the number of kids which go through education system in China and the fierceness in terms of competitive environment is extreme here. It's extreme."(China-Global-Real-Estate-Agent)

“...education in China, as you know, it's hugely competitive...I mean there's just huge pressure, especially at the end of high school exams, getting in to university. Because there's pressure from parents, there's pressure from peers and some people who are caught in that system, you know, it's viewed as a make or break." (China-Global-Property-Researcher)

"There's a big emphasis in terms of trying to give your kids the best in life. Not necessarily through emotional connection, but by getting them the best school or getting the best this or the best that...I don't know if they're a feeling a little bit guilty about not spending the time, but they'll spend the money if they want to give their kids the best chance in life." (China-GlobalReal-Estate-Agent)

“...I'm talking about preliminary and high schools. Here we go out to about competition, compete with lot of guys, a lot of children.” (China-Global-Real-Estate-Agent)

\subsection{China Macro Economy and Government Policies - Push Factors}

\subsubsection{Marco Economy Conditions in China}

Interview participants from China provided some insights of main drivers resulting in China outward FDI to other parts of the world, including Australia. These outward investment rationales constitute the "Push Factors" for this study as accordance with the "Push \& Pull" model stipulated in Section 3.1. The major "push" factors are listed as below, based on the interview results:

i. Limited investment options in China

ii. Underperforming domestic residential property market

iii. Relaxation of China restriction on investments outflowing to overseas

iv. Diversification to overseas assets 


\section{Quotes from participants:}

"Chinese people, you know, they have only two choices for investment: One, house; one stock market.....so you can see the past three or four years the stock market is very low...Chinese house, the price already too high....compared with properties in US, Australia or some UK house, it's good and cheap."(China-Local-Property-Consultant)

"...before they put it in to residential housing in China, because it was a performing market. But over the last two years, because of the cooling measures, it hasn't been a performing market so they looked at other markets elsewhere. And you know, they've decided on markets like Australia."'(China-Global-Property-Researcher1)

"Purely from an investment standpoint, because over the last two to three years we've seen the sort of underperformance of the China residential market because of the not so restricted, restrictive government policies put in place..... they've seen maybe better performance in other markets like certain cities in Australia."( China-Global-Property-Researcher2)

"Three reason...Firstly is diversification...Secondly is the China property market is not so well at the moment...there is Chinese Government now is not so strict(on offshore investments). Sometimes they encouraging."(China-Local-Real-Estate-Agent)

“...A. because it was just part of maturing their business, to diversity their assets overseas, and a lot of them weren't getting the returns that they once were in China. Obviously there's a slow-down in the economy here...so that drove them to go overseas and explore other options...B: maintain their development margins that they'd seen in China, over sort of the previous decade...the third thing is China Government is not encourage but they are not stopping... So people can send their money to overseas."(China-Global-Researcher-1)

"One of the key things is just that it's quite hard to get a good return on capital in the China market, the investment channels are relatively limited...you've got obviously the stock market, which for a long time hasn't been performing, you can't - interest rates or deposit-deposit rates which are relatively low, and historically they've just been just above inflation. And real estate investment has probably been one of the best ones, where there's actually been good values increasing...so I think it's saying, 'I've got this capital, I don't know where to put it. I can't find anywhere in China that, sort of, meets my needs in terms of my risk profile or my returns on trying to generate,' so sometimes they look at overseas markets"(China-GlobalReal-Estate-Agent)

\subsubsection{Wealth Accumulations and China "One-Child" Policy}

Significant wealth was created among the Chinese residents due to both the country's phenomenal economic growth and the implementation of its social economic "one-child" policy. As the "onechild" policy had been recently officially ended and was being replaced by a "two-child" policy in 2015 , this study presented the unique " $1+1=2$ " phenomenon in China that had impacted the fundamentals of both social and economy of China for the past decades. Wealth creation and accumulation experienced a "doubled-up" effect in the second generation of China one-child policy, mainly due to the wealth created in the first generation had flowed down to the second generation when they setup their own households. This phenomenon had led to enormous wealth liquidity among the young Chinese families, available to be invested both locally and internationally.

\section{Quotes from Participants:}

"Because why...China last 14 years accumulate lots of money. People accumulate, because this last very long, from 2000 to 2015, very long”'(China-Local-Real-Estate-Agent) 
"So you invest a lot into your kids(in China).....there's a big emphasis in terms of trying to give your kids the best in life. Not necessarily through emotional connection, but by getting them the best school or getting the best this or the best that."(China-Global-Real-Estate-Agent).

".....their kids for their study plus in China the parents want to bring the best of things to their kids...So if they realise, okay, the education or the environment or something there, overseas better than China, they want to bring, send their children overseas."(China-Local-PropertyConsultant)

".....the way that the whole family is actually, sort of, structured in China is the kids should be looked after by their grandparents.....they'll spend the money if they want to give their kids the best chance in life.."(China-Global-Real-Estate-Agent)

\subsubsection{Primary Push Factor - China "Going-Out" Policy}

China's "going-out" policy since 1999 had further fuelled the momentum for Chinese to invest in overseas markets. Whilst the State Owned Enterprises and private entities from China were actively engaged in international merger and acquisition exercises, wealthy Chinese private investors were pursuing the world property market. In the wave of China substantial investment in offshore market, Australia emerged as the second highest recipient of China Outward FDI in 2014 (Ernst\&YoungChina, 2015).

\section{Quotes from Participants:}

"The government policy...encourages the people to invest in overseas. Chinese Shanghai city governor a few days (ago) announced a new policy to try to encourage people to invest overseas. Why? Chinese currency should become global currency"(China-Local-PropertyResearcher)

"If the money stays(in China), and is forced to stay, then it just keeps fuelling higher prices, because it can't get out... if you're going to restrict what people can invest in, you create imbalances, those imbalances are not healthy...they've got their own problems with demand exceeding supply in their first-tier cities. The issue is, 'okay, we've got to take some of that money that would be going into those first-tier cities and let it out into the world."(ChinaGlobal-Property-Researcher1)

"I think money is too much; they want to change its, US dollar or something like that. So that's why you can see a lot of Chinese company invest overseas. That's actually the government encourage to do some overseas investment, to transfer the RMB to overseas. That's why they say in recent years that Chinese government will study when and how the RMB, make RMB to international currency. "(China-Local-Property-Consultant)

"if you look at the insurance companies since 2002, they've essentially been let off the leash to invest up to $15 \%$ of their assets in overseas real estate."(China-Global-Property-Researcher2)

\section{CONCLUSION}

The aim for this study is to explore evidences of a relationship between overseas investments and the Australian residential housing markets performance, particularly in areas that has experienced significant growth subsequent to GFC 2008. An emerging determinant of Residential Tourism (RT) is introduced to determine the extent of which this new driver shaping the development of Australian residential housing market. A series of semi-structured interviews were conducted in China to seek latest market information and verification to justify the findings that Australian residential property market was increasingly influenced by overseas conditions and RT had 
emerged as a new driver that should be taken into account for future evaluation of Australian residential property market.

Australia property as an investment portfolio is becoming an increasing obvious option to the world investor community. Although the focus of this study is on China investors, all participants commented that private investors from other Asia Pacific countries were equally interested in Australia real estates. Australia has emerged internationally relevance in many aspects and highly ranked in terms of stability and liveability. The brand presence of Australia as a safe and liveable country is to a large extend, similar to big international brands like Apple or Mercedes, in that it commands high respects and premium status compared to other parts of the world. It is believed that as long as Australia continues its favourable brand image internationally, foreign investors from all over the world, not just China, would continue to invest in Australian residential property market. This certainly has exerted a new dimension into the property market.

Residential Tourism is a new driver in Australian residential property market validated in the semistructured interviews conducted in China. As mentioned in earlier sections, Australian cities were internationally renowned for its "relative picture of stability" in terms of society, healthcare, culture and environment, education and infrastructure. The Residential Tourists from China demonstrate two unique characteristics:

i. High Net Worth Individuals (HNWIs) who do not position permanent residency as their top priority. They turn tourism into a way of life and live a fluid, leisure lifestyle between major gateway cities in the world. They purchase residential properties in Australia with the objective of enjoying Australia's favourable living conditions as tourists and imputed business sense in the assets they purchased by earning the rental yield and capital returns.

ii. Middle class -With the ultimate intention of getting a permanent residency in Australia, this group of investors began by travelling to Australia as tourists and then their visitations to Australia became a repetitive affair after their children's enrolment into Australia colleges.

Assessment on China government policies was proven a challenging phase of the research both in terms of sensitivity and complexity nature of the topic. Guided by the "Push and Pull" model of this study, an open-ended approach was employed in the interviews to solicit in-depth coverage of the issue while carefully avoiding elements which were potentially sensitive.

Significant wealth was created and accumulated among the Chinese due to both phenomenal economic growth and the social economic impact of "one-child" policy. This study presented the unique " $1+1=2$ " phenomenon in China that had impacted all aspects of the Chinese society for the past decades. Wealth experienced a "doubled-up" effect due to both the creation and accumulation in the first generation's wealth that was passed down to the second generations of "one-child" policy. They merged the wealth of two families into one newly married couple and created a new generation of wealthy young Chinese families, ready to be invested both locally and internationally.

China "going-out" policy since 1999 had further invigorated the momentum for Chinese to invest in overseas markets. Whilst the State Owned Enterprises and private entities from China were actively engaged in international merger and acquisition exercises, wealthy Chinese private investors pursued the world property market. In the wave of China substantial investment in offshore market, Australia emerged as the second highest recipients of this Outward FDI in 2014.

Figure 10 shows the pictorial representation of Australian residential property market model simulated based on the major "push" factors from offshore government policies, coupled with the significant "pull" factors from Australian government policies and the resultant interactions of property, space and capital market determinants: 


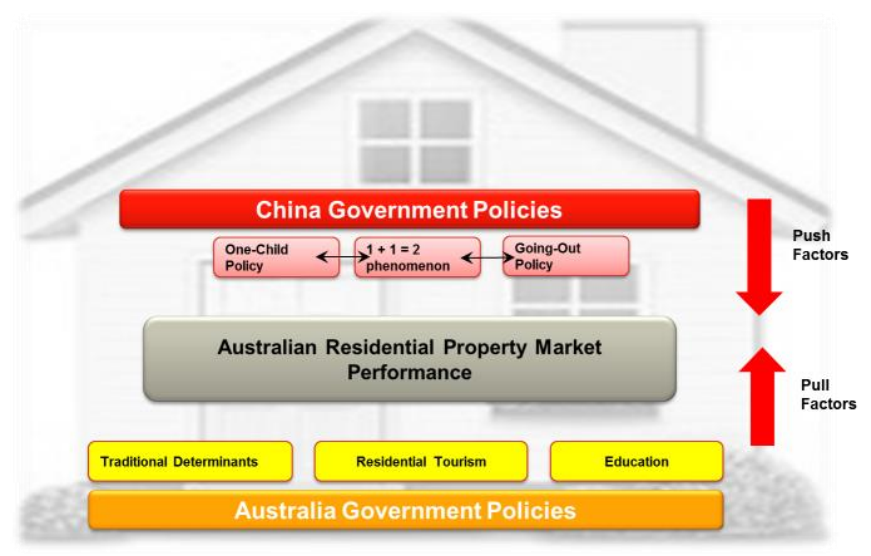

Current Australian residential property market performance is uniquely shaped by both foreign government policies and Australian government policies as depicted in Figure 10. Current evaluation measures on Australian residential property market performance are perceived inadequate due to its performance evaluation being heavily focused on domestic conditions and drivers. It is undoubtedly the Australian government policies in the area of foreign investment, education, immigration, tourism and social security benefits have provided the much needed foundation for a favourable investing environment. As the world becoming more transparent fuelled with globalization and advancement in information technologies, these favourable drivers were fast acted upon by global real estate investors engaging in cross border real estate transactions in Australia. China investors were the subject of study in this assessment which saw the impacts of "one-child" social policy and "going-out" policy that had pushed China investors actively pursuing cross border real estate investments. 


\section{Appendix I: $\quad$ Proposed Semi-Structured Interview Questions}

\section{Information on your Organisation}

1. Which overseas property markets does your organisation operate within (both geographically and scale)?

2. How does your organization service Chinese investors who wish to invest in overseas property market?

\section{Information on China Investor Overseas Investments}

1. What are the different characteristics and types of Chinese investors who invested in overseas residential property market?

2. Focusing on private investors from China, what do you perceive are the main drivers for their investment in overseas residential property markets?

- Are these drivers mainly specific factors or are they economic and social factors that encouraged overseas investments?

- What are any other considerations, for example capital preservation, taxation? Please explain.

\section{Property Market Conditions}

1. Assessing past and present, which type of properties do China private investors prefer and why?

2. Compared to other overseas investment destinations, how has Australia performed in:

- Sales : Competition, features, types of purchases?

3. What are the major local factors in Australia (Melbourne) that attract Chinese property investors to buy residential properties?

\section{Information on Education and Tourism}

1. Will the investors regularly visit locations interested prior to residential property purchase? If yes, why and with who?

2. Do you perceive the education system play a role in these investors' decision making? How significant is Australian education system influences these overseas investors' decision on residential property market?

3. What is the role of the living standards and conditions (tourism) of Australia on Chinese investors' choice and decision makings when it comes down to buying overseas residential properties? 
Appendix II: Codes for China Property Professionals

\begin{tabular}{|c|c|c|c|}
\hline $\begin{array}{l}\text { Role in } \\
\text { Organizatio } \\
\text { n }\end{array}$ & Type of Organisation & $\begin{array}{l}\text { Location/Coverag } \\
\text { e }\end{array}$ & $\begin{array}{l}\text { Code to be used } \\
\text { for analysis }\end{array}$ \\
\hline $\begin{array}{l}\text { Associate } \\
\text { Director }\end{array}$ & $\begin{array}{l}\text { Real estate consultant - } \\
\text { Global multi-disciplinary } \\
\text { property organization, } \\
\text { property agent serving all } \\
\text { types of property markets }\end{array}$ & $\begin{array}{l}\text { Shanghai, } \\
\text { China }\end{array}$ & $\begin{array}{l}\text { China-Global- } \\
\text { Real-Estate-Agent }\end{array}$ \\
\hline Owner & $\begin{array}{l}\text { China Property Agent } \\
\text { serving overseas property } \\
\text { investments and } \\
\text { international property } \\
\text { conference organiser }\end{array}$ & $\begin{array}{l}\text { Shanghai, } \\
\text { China }\end{array}$ & $\begin{array}{l}\text { China-Local- } \\
\text { Real-Estate-Agent }\end{array}$ \\
\hline $\begin{array}{l}\text { Director, } \\
\text { Head of } \\
\text { China } \\
\text { Strategy } \\
\text { Research }\end{array}$ & $\begin{array}{l}\text { Real estate researcher - } \\
\text { Global multi-disciplinary } \\
\text { property organisation } \\
\text { serving all types of } \\
\text { property markets }\end{array}$ & $\begin{array}{l}\text { Shanghai, } \\
\text { China }\end{array}$ & $\begin{array}{l}\text { China-Global- } \\
\text { Property- } \\
\text { Researcher1 }\end{array}$ \\
\hline $\begin{array}{l}\text { Head of } \\
\text { Research }\end{array}$ & $\begin{array}{l}\text { Real estate researcher - } \\
\text { Global muti-disciplinary } \\
\text { property organization } \\
\text { serving all types of } \\
\text { property markets }\end{array}$ & $\begin{array}{l}\text { Shanghai, } \\
\text { China }\end{array}$ & $\begin{array}{l}\text { China-Global- } \\
\text { Property- } \\
\text { Researcher2 }\end{array}$ \\
\hline President & $\begin{array}{l}\text { Shanghai local property } \\
\text { surveyor and agent }\end{array}$ & $\begin{array}{l}\text { Shanghai, } \\
\text { China }\end{array}$ & $\begin{array}{l}\text { China-Local- } \\
\text { Property- } \\
\text { Researcher }\end{array}$ \\
\hline $\begin{array}{l}\text { General } \\
\text { Manager }\end{array}$ & $\begin{array}{l}\text { International Merchant } \\
\text { Banker - providing cross } \\
\text { border financing and } \\
\text { transactional services }\end{array}$ & $\begin{array}{l}\text { Shanghai, } \\
\text { Beijing China }\end{array}$ & $\begin{array}{l}\text { China-Global- } \\
\text { Financial- } \\
\text { Consultant }\end{array}$ \\
\hline $\begin{array}{l}\text { Vice } \\
\text { President }\end{array}$ & $\begin{array}{l}\text { Fund Manager and } \\
\text { Consultant }- \text { providing } \\
\text { advisory services to } \\
\text { companies and clients on } \\
\text { investment }\end{array}$ & $\begin{array}{l}\text { Shanghai, } \\
\text { Beijing China }\end{array}$ & $\begin{array}{l}\text { China-Local- } \\
\text { Property- } \\
\text { Consultant }\end{array}$ \\
\hline
\end{tabular}




\section{REFERENCES}

ABS 2015. 6416.0-Residential Property Price Indexes: Eight Capital Cities, Sep 2015. Australian Bureau of Statistics, Canberra, viewed 10 October 2015,

<http://www.abs.gov.au/ausstats/abs@.nsf/mf/6416.0>

ALLEN, L. 2015. Chinese Precise On Where To Buy. the Australian Financial Review, 22 July, viewed 23 July 2015,

<http://www.theaustralian.com.au/subscribe/news/1/index.html?sourceCode=TAWEB_WR

E170_a\&mode=premium\&dest=http://www.theaustralian.com.au/business/businessspectator/australia-is-still-hot-property-for-foreign-investors>

BOYNE, S., CARSWELL, F. \& HALL, D. 2002. Reconceptualising VFR tourism. Tourism and Migration. Canberra: Springer.

COMMONWEALTHBANK, A. 2014. Demand and House Prices. Global Market Research Eonomics: Issues. Sydney: Australian Commonwealth Bank.

CULEM, C. G. 1988. The locational determinants of direct investments among industrialized countries. European economic review, 32, 885-904.

CUSHMAN, D. O. 1987. US bilateral trade balances and the dollar. Economics Letters, 24, 363367.

D'ARCY, É. 2009. The evolution of institutional arrangements to support the internationalisation of real estate involvements: Some evidence from Europe. Journal of European Real Estate Research, 2, 280-293.

DWYER, L. 2010. Migration-Related Determinants Of Australian Inbound And Outbound Tourism Flows. Sustainable Tourism Cooperative Research Centre.

DWYER, L., FORSYTH, P., BURNLEY, I. \& MURPHY, P. 1993. Economic impacts of migration induced inbound tourism. Discussion Paper Series-School of Business \& Technology, University of Western Sydney.

ECONOMICS, H. S. C. O. 2014, Inquiry into foreign investment in residential real estate. Committee activities (inquiries and reports), House Standing Committee on Economics, viewed 25 July 2014, <http://www.aph.gov.au/Parliamentary_Business/Committees/House_of_Representatives_C ommittees?url=economics/foreigninvestment/index.htm>

ECONOMIST 2012, The New Landscape of Foreign Investment into China, The Economist, viewed 12 August 2014, <http://pages.eiu.com/rs/eiu2/images/EIU_ChinaFDIJan2012_Final.pdf>

ERNST\&YOUNG 2013, 'Hitting The Sweet Spot The Growth of the Middle Class In Emerging Market', Ernst \& Young, viewed 8 June 2015, <http://www.ey.com/Publication/vwLUAssets/Hitting_the_sweet_spot/\$FILE/Hitting_the_s weet_spot.pdf>

ERNST\&YOUNGCHINA 2015, 'Riding The Silk Road: China Sees Outbound Investment Boom', Ernst \& Young China, viewed 10 July 2015, $<$ http://www.ey.com/Publication/vwLUAssets/ey-china-outbound-investment-reporten/\$FILE/ey-china-outbound-investment-report-en.pdf>

FIRB 2013, Annual Report 2012-13. In: BOARD, F. I. R. (ed.), industry report, Foreign Investment Review Board, viewed 5 May 2014, retrieved from <https://firb.gov.au/files/2015/11/FIRBAnnual-Report-2012-13.pdf> 
FREY, B. S., SCHNEIDER, F. \& POMMEREHNE, W. W. 1985. Economists' opinions on environmental policy instruments: analysis of a survey. Journal of Environmental Economics and Management, 12, 62-71.

FROOT, K. A., PEROLD, A. F. \& STEIN, J. C. 1991. Shareholder trading practices and corporate investment horizons. National Bureau of Economic Research.

GARNAUT, J. 2015, 'Five Million Visas Into Australia This Year Likely To Set New Records, The Age, 22 April, viewed 5 May 2015, <http://www.smh.com.au/federal-politics/politicalnews/five-million-visas-into-australia-this-year-likely-to-set-new-records-20150421$1 \mathrm{mq} 6 \mathrm{~km} \cdot \mathrm{html}>$

GOLDBERG, L. G. \& JOHNSON, D. 1990. The determinants of US banking activity abroad. Journal of International Money and Finance, 9, 123-137.

HAWTHORNE, L. 2010. “Two-Step Migration”? Labor Market Outcomes for International Student Migrants to Australia. Asian and Pacific Migration Journal, 19, 5.

HIGGINS, D. 2010. The Impact of the Political Cycle on House Prices: The Australian Experience. Asian Real Estate Society Conference.

HIGGINS, D. \& REDDY, W. 2010. The impact of political risk on Australian house prices. Australian and New Zealand Property Journal, 2, 413-422.

JANDA, M. 2014, 'Chinese buyers to invest \$44b in Australian real estate', ABC News, 5 March, viewed 10 March 2014, <http://www.abc.net.au/news/2014-03-05/chinese-buyers-to-invest44-billion-dollars-in-australian-real-/5300494>

KHARAS, H. 2010. The Emerging Middle Class in Developing Countries. OECD Working Paper, 285.

KING, B. 1994. What is ethnic tourism? An Australian perspective. Tourism Management, 15, 173176.

KING, N., CASSELL, C. \& SYMON, G. 1994. Qualitative methods in organizational research: A practical guide. The Qualitative Research Interview.

KPMG 2014. Demystifying China Investment in Australia. Sydney: KPMG.

LUCAS, C. 2015, 'Melbourne Named World's Most Liveable City, For Fifth Year Running', The Age, 19 August, viewed 19 August 2015, <http://www.theage.com.au/victoria/melbournenamed-worlds-most-liveable-city-for-fifth-year-running-20150818-gj1 he $8 . \mathrm{html}>$

MOSHIRIAN, F. \& PHAM, T. 2000. Determinants of US investment in real estate abroad. Journal of Multinational Financial Management, 10, 63-72.

NAB 2015, NAB Residential Property Survey: Q1 2015, National Australia bank, viewed 1 May 2015, <http://business.nab.com.au/wp-content/uploads/2015/04/Quarterly-AustralianResidential-Property-Survey-Q1-2015-PDF202KB.pdf>

O'REILLY, K. 2007. Emerging tourism futures: Residential tourism and its implications.

PASCOE, M. 2015, 'Foreign Students Set To Power Housing', The Sydney Morning Herald Business Day, 4 August, viewed 10 August 2015, <

http://www.smh.com.au/business/comment-and-analysis/foreign-students-set-to-powerhousing-20150803-giq47c.html>

RODRÍGUEZ, C. \& BUSTILLO, R. 2010. Modelling foreign real estate investment: The Spanish case. The Journal of Real Estate Finance and Economics, 41, 354-367. 
SAVILLS 2014, Around The World In Dollars and Cents - How Private Money Moves Around The Real Estate World, Savills World Research 2014, viewed 20 July 2014, <http://www.savills.co.uk/research_articles/188297/171998-0>

SCHLESINGER, L. 2015, 'Chinese property buyer myths busted', Financial Review, 1 March, viewed 8 March 2015, <http://www.afr.com/real-estate/residential/chinese-property-buyermyths-busted-20150227-13r0n4>

TEDDLIE, C. \& TASHAKKORI, A. 2009. Foundations of mixed methods research: Integrating quantitative and qualitative approaches in the social and behavioral sciences, Sage Publications Inc.

TEDDLIE, C. \& YU, F. 2007. Mixed methods sampling a typology with examples. Journal of mixed methods research, 1, 77-100.

TIMESHIGHEREDUCATION 2015, 'World University Rankings', Times Higher Education, viewed 23 October 2015, < https://www.timeshighereducation.com/world-universityrankings/2015/world-

ranking\#!/page/0/length/25/sort_by/rank_label/sort_order/asc/cols/rank_only>

TOPINTZI, E., CHIN, H. \& HOBBS, P. 2008. Moving towards a global real estate index. Journal of Property Investment \& Finance, 26, 286-303.

UNCTAD 2009, World Investment Report 2009 - Transnational Corporations, Agricultural Production and Development, United Nation Conference on Trade and Development, viewed 5 April 2014, <http://unctad.org/en/docs/wir2009_en.pdf>

UNCTAD 2011, NON-EQUITY MODES OF INTERNATIONAL PRODUCTION AND

DEVELOPMENT. World Investment Report 2011. United Nation Conference on Trade and Development, viewed 28 April 2014, <

http://unctad.org/en/pages/PublicationWebflyer.aspx?publicationid=84>

UNCTAD 2013. World Investment Report 2013 - Global Value Chains: Investment And Trade For Development. United Nations Conference on Trade and Development, viewed 28 April 2014, <http://unctad.org/en/pages/PublicationWebflyer.aspx?publicationid=588>

WILLIAMS, A. \& HALL, C. M. 2002. Tourism, migration, circulation and mobility. In: HALL, C. M. \& WILLIAMS, A. (eds.) Tourism and Migration. Springer Netherlands.

WILLIG, C. 2013. Introducing qualitative research in psychology, McGraw-Hill Education (UK).

WILSON, D. 2008. The Expanding Middle: The Exploding World Middle Class and Falling Global Inequality. Goldman Sachs Global Economy Paper, 170.

YIN, R. K. 2013. Case study research: Design and methods, Sage publications. 